\title{
UKM LOUNDRY UNTUK PENINGKATAN KESEJAHTERAAN DI KAMPUNG GEBANG SIDOARJO
}

\author{
Muharom $^{1}$, Krisnadhi Hariyanto ${ }^{2}$ \\ Universitas Wijaya Putra Surabaya ${ }^{1.2}$ \\ Muharom@uwp.ac.id ${ }^{1}$, Krisnadi@uwp.ac.id ${ }^{2}$
}

\begin{abstract}
ABSTRAK
Kelurahan Gebang merupakan salah satu kelurahan yang berada disisi paling timur dari Kecamatan Sidoarjo, Kabupaten Sidoarjo. Perkembangan kelurahan Gebang ini sangat pesat setelah dibangunnya jalan lingkar timur Sidoarjo yang membelah perkampungan Gebang menjadi dua yaitu disisi timur dan sisi barat jalan. Dengan adanya jalan lingkar timur tersebut warga Kelurahan Gebang meningkat sangat signifikan, diantaranya karena banyak dibangun perumahan dan kawasan pergudangan dan industri. Pada UKM Izzah yang ada dikelurahan Gebang khususnya yang bergerak dibidang jasa loundry sebagian dari mereka membutuhkan area penjemuran untuk membantu proses pengeringan. Bagi masyarakat yang mempunyai mata pencaharian sebagai jasa loundry sangatlah mutlak membutuhkan panas setiap hari untuk membantu pengeringan cucian. Untuk mengatasi masalah faktor cuaca yang sering hujan dan lahan yang sempit team kami melakukan inovasi desain pembuatan alat pengering baju untuk mempercepat proses pengeringan dan menanggulangi lahan yang sempit tadi. Disamping itu juga memberikan pelatihan menejemen administrasi dan keuangan serta inovasi produk. Hasil pengukuran di laboratorium /bengkel mesin Teknik mesin UWP memperlihatkan bahwa mesin pengering pakaian bekerja dengan beban 50 baju basah hasil perasan tangan, kondisi udara masuk di dalam lemari pengering mampu mencapai suhu udara kering sekitar $74^{\circ} \mathrm{C}$, dengan suhu udara basah sekitar $34^{\circ} \mathrm{C}$. Dari data hasil pengukuran, dengan kondisi udara seperti tersebut, udara mempunyai kemampuan untuk mengeringkan baju- baju yang ada di dalam ruang pengering.
\end{abstract}

Key word : Inovasi produk, Desain Mesin Pengering baju, Pelatihan menejemen

\section{PENDAHULUAN}

\section{Analisis Situasi}

Pada UKM yang ada dikelurahan Gebang khususnya yang bergerak dibidang jasa loundry sebagian dari mereka membutuhkan area penjemuran untuk membantu proses pengeringan. Bagi masyarakat yang mempunyai mata pencaharian sebagai jasa loundry sangatlah mutlak membutuhkan panas setiap hari untuk membantu pengeringan cucian. Untuk mengatasi masalah faktor cuaca yang sering hujan dan lahan yang sempit maka team kami ingin mencoba melakukan inovasi pembuatan alat pengering baju untuk 
mempercepat proses pengeringan dan menanggulangi lahan yang sempit tadi. Proses pengeringan yang dilakukan saat ini masih bersifat sederhana yaitu dengan metode penjemuran secara langsung dibawah sinar matahari dan juga ada yang sudah menggunakan alat pengering tapi hasilnya kurang maksimal efisien.

Mempertimbangkan kekurang efisienan dan ke efektifan metode yang ada maka perlu dicari suatu metode yang tepat untuk dapat menggantikannya, namun masih memiliki fungsi yang sama yaitu sebagai pengering yang dapat menurunkan kadar air lebih cepat dan lebih efisien. Pengeringan pada jasa loundry cuci basah biasanya ada dua macam yaitu pengeringan $90 \%$ dari mesin yang bisa langsung disetrika yang kedua pengeringan $60-80 \%$ dari mesin yang tentunya tidak memungkinkan untuk langsung disetrika, jadi perlu penjemuran atau diangin-anginkan dulu yang tentunya membutuhkan tempat. Pengeringan alami adalah dengan mengandalkan panas dari terik matahari sementara pengeringan buatan merupakan cara pengeringan dengan menggunakan alat yang memanfaatkan sumber panas lain selain sinar matahari langsung, misal kompor gas, atau tenaga listrik.

Udara mempunyai kandungan uap air yang lebih kecil dari pada bahan sehingga dapat menghisap uap air dari bahan yang dikeringkan. Salah satu faktor yang mempercepat proses pengeringan adalah angin atau udara yang mengalir. Dengan adanya aliran udara maka udara yang sudah jenuh dapat diganti oleh udara kering sehingga proses pengeringan dapat berjalan secara terus menerus. Namun demikian jumlah tenaga kerja pada mitra tersebut tidak jauh beda mempunyai karyawan berjumlah 2 orang. Mengenai jenjang pendidikan dan umur usaha loundry di mitra tersebut adalah jenjang SMA serta rata-rata usia mereka adalah 22 tahun. Kapasitas output berkisar $200-300 \mathrm{~kg}$ / hari.

\section{Permasalahan}

Mitra tersebut berdiri sejak tahun 2013an, tenaga yang dipekerjakan ada 2-3 orang pekerja yang berasal dari tetangga dengan sistem kekeluargaan dan sebagian besar sistem administrasi keuangan belum teratur serta tidak mempunyai pembukuan. Proses cuci setrika dari mitra tersebut tidak bisa melayani laundry kilat atau dibawah waktu 6 jam. Kecuali untuk cuci basah, hal tersebut karena kedua mitra tersebut belum mempunyai mesin pengering pakaian, juga tidak mempunyai lahan untuk penjemuran yang memadai. Dengan demikian tidak bisa menerima jasa cuci setrika yang bervariasi dan kilat. Mitra tersebut hanya mengandalkan strategi pemasaran secara "word of mouth" (mulut ke mulut) dan juga tidak memiliki kemampuan analisis pasar dengan baik serta harga jual disesuaikan / dipengaruhi oleh daya beli masyarakat di pasaran sehingga mitra tersebut dituntut untuk meminimalkan harga pokok produk agar laba yang diperoleh tetap stabil.

Sumber daya manusia (SDM) merupakan bagian penting untuk meningkatkan produktivitas usaha baru. SDM kedua mitra membutuhkan peningkatan keterampilan proses cuci / pengeringan pakaian yang efektif, bermutu dan higienis. Mitra tersebut belum memaksimalkan daya kreativitas dan peluang yang ada serta belum melakukan inovasi dan diferensiasi produk sehingga produk yang ditawarkan ke pasar masih belum ada perubahan atau sama dengan keadaan awal saat berdiri dengan kata lain bahwa mitra tersebut tidak berani terhadap resiko yang dihadapi (risk aventer). Saat ini mitra tersebut hanya mencatat segala pengeluaran bahan utama, bahan pembantu dan lain-lain dalam sebuah buku catatan, sedangkan mengenai biaya tenaga kerja belum dimasukkan sebagai ongkos produksi. Perencanaan usaha lebih banyak didasarkan pada perkiraan saja tanpa didukung oleh data keuangan serta aktivitas riil usahanya

Teknologi Informasi dan Komunikasi 
mitra masih bingung untuk menentukan cara mendapatkan laba usaha. Pada proses produksi pengeringan mitra masih menggunakan peralatan yang kurang hiegienis. Hal ini akan berdampak pada rendahnya tingkat hiegienisitas proses produksi serta tingkat jaminan mutu produk bagi konsumen.

\section{METODE PELAKSANAAN}

Teknik pelaksanaan dengan model kunjungan semingggu sekali ke mitra serta dosen pelaksana tetap melakukan kegiatan pendampingan dan monitoring hingga kegiatan PKM berakhir. Kegiatan pendampingan yang dilakukan meliputi kegiatan observasi, brainstorming dan diskusi, upaya perbaikan produk (kemasan, inovasi), pengoperasian mesin pengering, perbaikan administrasi keuangan, pemilihan pasar potensial serta cara pemasaran produk, penerapan manajemen mutu dan kesehatan produk yang hiegienis. Kegiatan PKM dari sisi manajemen adalah bagaimana upayaupaya untuk mempromosikan usaha, sistem pengelolaan manajemen. Upaya yang dilakukan untuk melakukan promosi adalah dengan membuat label / merk serta kemasan yang menarik di tiap-tiap pemilik usaha loundry. Cara tersebut diharapkan masyarakat mengetahui usaha loundry ini sehingga efek promosi dapat dirasakan oleh pemilik usaha loundry tersebut. Selain itu upaya promosi untuk memperkenalkan pemilik usaha loundry serta secara menyeluruh di Kecamatan Sidoarjo.

Upaya desain rancang bangun yang dilakukan adalah pembuatan mesin pengering. Metode ini diharapkan dapat membantu dalam proses pengeringan di saat keadaan kurang sinar matahari (mendung). Model ini sebatas desain yang diharapkan nantinya usaha loundry itu sendiri membuat dalam ukuran dengan material yang lebih kokoh. Pembuatan mesin pengering pakaian ini nantinya digunakan untuk tempat meletakkan pakaian setelah dicuci sebagai proses pengeringan. Dengan hal tersebut manfaat yang dirasakan adalah waktu pengeringan cepat.
Pelatihan administrasi keuangan lebih banyak ditekankan pada upaya perbaikan pembukuan. Ini dilakukan karena semua pemilik usaha loundry ini belum memiliki sistem pembukuan, semua masih dilakukan secara campur aduk. Pelatihan dilakukan pada pembuatan catatan pembukuan keuangan sederhana. Ini dilakukan supaya pemilik usaha dapat memisahkan antara keuangan usaha dengan keuangan keluarga, dapat menghitung harga pokok produksi dan akhirnya dapat menghitung laba / rugi usaha. Pelatihan manajemen mutu dan kesehatan diupayakan untuk semakin mengenalkan pemilik usaha loundry tentang cara cuci setrika yang sehat dan hiegienis. Pelatihan ini ditujukan kepada pemilik usaha loundry untuk mengetahui proses produksi yang tepat, penggunaan peralatan yang hiegienis

\section{HASIL DAN PEMBAHASAN}

Hasil pengujian yang telah dilakukan di bengkel/laboratorium teknik mesin UWP memperlihatkan bahwa mesin pengering yang bekerja dengan sistem tertutup dapat bekerja dengan baik. Mesin dapat menyala dan dapat bekerja secara terus menerus tanpa terjadi kemacetan, kebocoran, hambatan dan gangguan .Untuk pengeringan dengan beban 50 baju basah hasil perasan tangan maupun 50 baju basah hasil perasan mesin cuci, disajikan pada Tabel 1 . Disajikan pula data pengeringan 50 baju basah hasil perasan tangan dengan mempergunakan energi surya. Pengambilan data dihentikan ketika massa baju yang dikeringkan sudah sama dengan massa awal baju kering sebelum dibasahi.

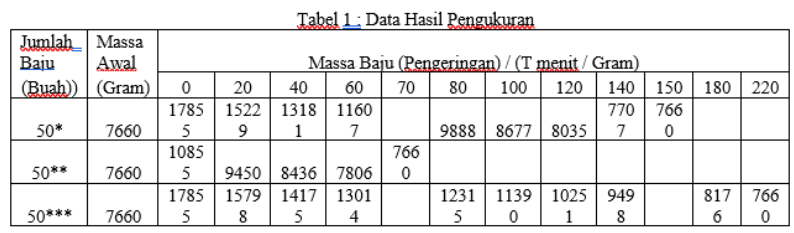

Kondisi udara luar rata rata $\mathrm{Tdb}: 28^{\circ} \mathrm{C}$ dan $\mathrm{Twb}$ : $26^{\circ} \mathrm{C}$. 
* : kondisi baju basah yang diperas dengan tangan

** : kondisi baju basah yang diperas dengan mesin cuci

*** : pengeringan baju basah hasil perasan tangan, yang dilakukan dengan sinar matahari

Hasil pengukuran memperlihatkan bahwa ketika mesin pengering pakaian bekerja dengan beban 50 baju basah hasil perasan tangan, kondisi udara masuk di dalam lemari pengering mampu mencapai suhu udara sekitar $74^{\circ} \mathrm{C}$, dengan suhu udara basah sekitar $34^{\circ} \mathrm{C}$. Dari data hasil pengukuran, dengan kondisi udara seperti, udara mempunyai kemampuan untuk mengeringkan baju baju yang ada di dalam ruang pengering.

Dari Tabel 1 di atas, dapat disimpulkan bahwa waktu yang diperlukan untuk mengeringkan baju bergantung dari kondisi awal atau perlakuan awal pakaian basah, diperas dengan tangan atau diperas dengan mesin cuci. Semakin basah kondisi awal pakaian, semakin lama proses pengeringannya. Dengan demikian langkah baik yang harus ditempuh adalah mencari jalan yang membantu memperkecil massa awal baju basah. Selain diperas dapat pula dilakukan dengan cara diangin-anginkan dan dapat pula dengan cara dikipasi dengan kipas angin. Kecepatan drum mesin cuci yang dipergunakan untuk memeras juga dapat dipilih dengan putaran yang tinggi. Waktu tercepat yang diperlukan untuk mengeringkan baju diperoleh jika kondisi awal baju basah diperas dengan mesin cuci. Waktu yang diperlukan untuk mengeringkan 50 baju basah hanya sekitar 70 menit, lebih cepat sekitar 80 menit dibandingkan diperas dengan tangan. Pengeringan dengan energi matahari, memerlukan waktu paling lama, untuk 50 baju hasil perasan tangan memerlukan waktu sekitar 220 menit. Informasi besarnya kecepatan pengeringan ini sangat penting dan berarti bagi orang yang bergerak dalam bisnis laundry.

Manajemen keuangan adalah suatu kegiatan perencanaan, penganggaran, pemeriksaan, pengelolaan, pengendalian, pencarian dan penyimpanan dana yang dimiliki oleh suatu organisasi atau perusahaan. Pada usaha laundry bagian ini meliputi : menetapkan kebijakan harga (tidak selalu yang murah di senangi pelanggan), melakukan pengawasan terhadap pengeluaran untuk operasional dan pemasukan dari pelanggan, melakukan pencatatan untuk uang/barang yang biasanya tertinggal di saku dan memastikan uang atau barang kembali pada pemiliknya dan menghitung nilai keuntungan usaha laundry tiap bulan. Setiap usaha pasti menghadapi beberapa kendala. Kadang-kadang terjadi pemadaman air PDAM dan Tenaga Listrik PLN yang bisa menyebabkan terhambatnya proses laundry. Untuk itu sebaiknya usaha laundry mempunyai tangki atau tandon air dan genset. Adanya kartu anggota pelanggan yang berisi data nama, alamat dan nomor telepon sangat diperlukan untuk memudahkan menghubungi pelanggan jika sewaktu-waktu terjadi kendala dalam proses laundry.
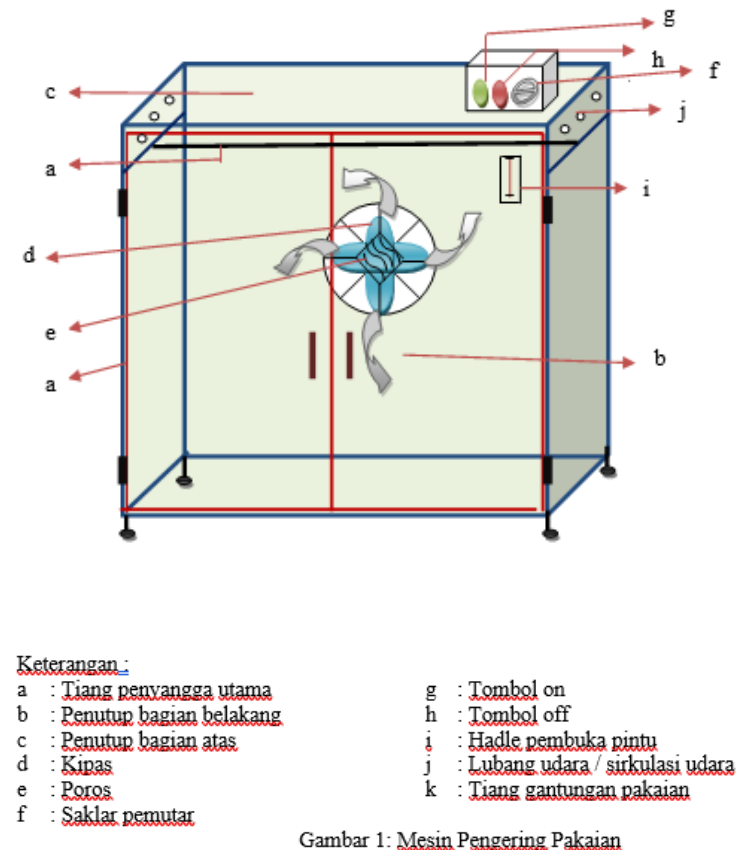

\section{KESIMPULAN}

Adapun kesimpulan yang didapatkan sebagai berikut :

1. Perbaikan teknologi yang telah diberikan pada mitra Izzah Laundry dapat memberikan

Teknologi Informasi dan Komunikasi 71 
manfaat dalam peningkatan usaha jasa pakaian menjadi lebih maksimal. Aplikasi penggunaan mesin spinning pakaian ini berdampak pada lama proses pengeringan karpet menjadi lebih cepat 3 kali dibandingkan dengan cara sebelumnya. Manajemen operasional dan bisnis yang baik dan tepat diperlukan dalam pengembangan bisnis industri kecil agar memiliki daya saing yang lebih besar. Strategi ini diberikan dalam bentuk workshop kepada pelaku usaha jasa laundry pakaian disekitar lokasi mitra PKM di daerah Kelurahan Gebang, Kec. Sidoarjo Sidoarjo.

2. Desain Mesin pengering dapat di buat dengan mudah oleh bengkel manapun dan di harapkan bekerja dengan baik, praktis, aman dan ramah lingkungan, tidak mengalami kemacetan di dalam bekerjanya. Kondisi udara masuk ruang pengering memiliki suhu udara kering sekitar $74^{\circ} \mathrm{C}$ dan suhu udara basah sekitar $34^{\circ} \mathrm{C}$. Untuk mengeringkan 50 baju basah hasil perasan tangan secara bersamaan memerlukan waktu sekitar 150 menit dan untuk baju basah hasil perasan mesin cuci memerlukan waktu sekitar 70 menit.

\section{DAFTAR PUSTAKA}

Arko Priyono \& Kreith, 1991, Prinsip-Prinsip Perpindahan Panas, Jakarta, Erlangga.

A. Walujodjati dan Darmanto, Rancang Bangun Mesin Pengering Kerupuk Untuk Industri Kecil Kerupuk, Jurnal Momentum, Vol. 1 No. 1, April 2005.

Baker, N.D. \& Ryder, E.A., 1987, Themperature Measurement In Engineering, Standford Omega Press.
Bergeyk Van., Liederken, A.J., 1987, Teknologi

Proses, Jakarta, Bhatara Karya Aksara.

Daryanto, Drs., 1987, Mesin Pengerjaan Logam, Bandung, Tarsito.

Filino Harahap, Reynold, W.C. \& Perkins, H.C., 1993, Thermodinamika Teknik, Jakarta, Erlangga.

Jasfi E., Holman, J.P., 1993, Perpindahan Kalor, Jakarta, Erlangga.

Kotler, Philip, 2003, Marketing Management, Engelwood Cliffs : Prentice Hall International Inc. Adivision of Simoon and Scuster.

Sriati japri, Van Vlack H., Lawrence, Ilmu dan Teknologi Bahan, Jakarta, Erlangga. 